\title{
Florida lures research institutes east
}

Florida is on a drive to recruit Californian research institutes, dangling tempting financial offers to persuade renowned laboratories to set up branches in the state.

At least three research institutes are jockeying for a share of the $\$ 245$ million recently allocated to job-creating projects in Florida. The organizations whose leaders are being wined, dined and flown to the state on private jets include the Burnham Institute, a biomedical research facility based in La Jolla, California; SRI International, a non-profit research institute in Menlo Park, known for developing Silicon Valley technologies; and the Torrey Pines Institute for Molecular Studies, also based in La Jolla.

The driving force behind the recruitment is Florida Governor Jeb Bush, a Republican and the brother of President George W. Bush. Earlier this year, Governor Bush got $\$ 245$ million from the Florida legislature to create high-tech industry jobs.

He is now using that money to woo research leaders from California, the state apparently most interested in what Florida has to offer. A state legislative committee is scheduled to meet on 17 August to consider proposals on how to divvy up the money.

Under Governor Bush's proposals, local governments will partner with a research institute and offer land and buildings worth nearly $\$ 100$ million. Each partnership will then ask the state to match that investment.

A 2003 agreement between Governor Bush, the county of Palm Beach, and the Californiabased Scripps Research Institute, to build a research complex with the Scripps name, provides a model for how this could work. So far, more than $\$ 90$ million has been spent on 'Scripps Florida, although no permanent buildings have yet been constructed.

Separately, Scripps has launched an initiative to build a leading centre for avian influenza research in Florida. Called Project Checkmate, the plan calls for Scripps to join forces with IBM's Thomas J. Watson Research Center in Yorktown Heights, New York. Researchers from both institutes would use supercomputers and a biosecure laboratory facility to try to predict each year's avian-flu mutations in advance.

"Biotechnology combined with large-scale computing could really move both fields for-

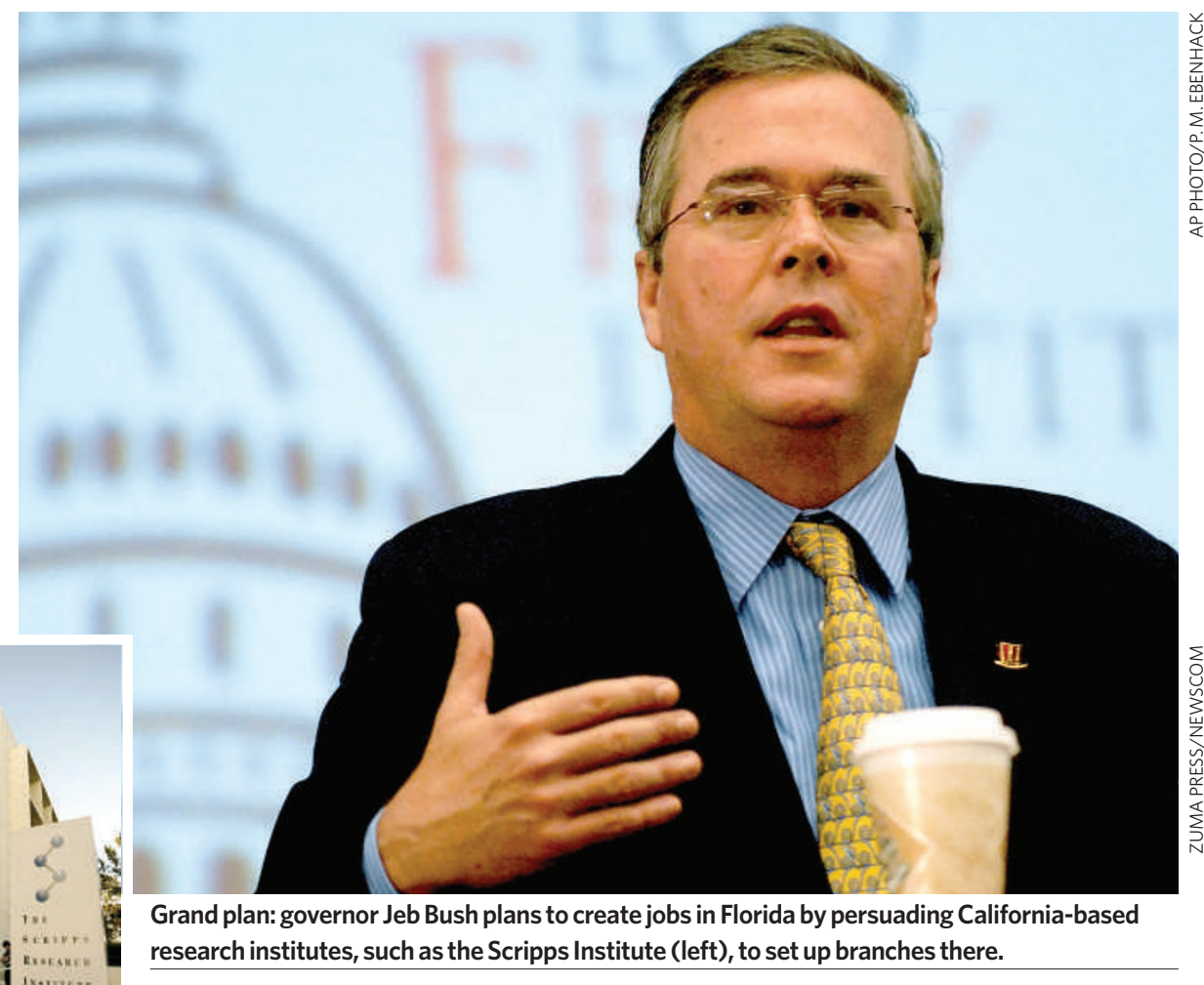

ward," says Ajay Royyuru, head of computational biology at IBM's Watson Center. Project leaders are seeking \$520 million over five years from the US National Institutes of Health, as well as $\$ 18$ million from Florida.

Many in Florida support such collaborations, saying they will bring much-needed jobs to the state. But not everyone is happy. "These are absolutely horrible deals, giving away the store," says Dan Gelber, a Democratic state representative from Miami Beach. Joseph Cortright, an Oregon-based economist who studies high-tech industries, agrees that pouring money into new facilities doesn't necessarily create better jobs or broad economic benefit to the region.

\section{Gold rush}

Some Florida universities also aren't thrilled. "The state needs to support research institutions that are already operating," says Abdul Rao, a vice-president for research at the University of South Florida. To help pay for the transfers, Governor Bush is proposing shifting millions of dollars from state-university budgets.

The president of the Burnham Institute, molecular biologist John Reed, says money was the principal reason the Burnham wants to add a Florida facility. In recent years the institute had asked California legislators for additional funding, but without success. Reed wouldn't comment on financial specifics of the deal, but the Burnham reportedly wants about $\$ 150$ million of the state's money.

Expanding into Florida, Reed argues, would raise the Burnham's profile. "I think it is a great advantage, having a presence at the national level," he says. The institute has narrowed possible locations for its expansion to the Orlando area and to Port St. Lucie on the Atlantic coast.

Meanwhile, SRI International has its eye on creating a water-research facility near Tampa, in conjunction with the University of South Florida. Project costs weren't available, and SRI officials declined to comment.

As for the Torrey Pines Institute, it plans to partner with governments in either Boca Raton or elsewhere in Palm Beach County and hopes to eventually have 20 principal investigators there. The institute was personally recruited by Governor Bush, says chemist Richard Houghten, its president and founder. "It's very exciting," he says.

Rex Dalton

With additional reporting by Emma Marris 